\title{
Drawings as imaginative expressions of philosophical ideas in a Grade 2 South African literacy classroom
}

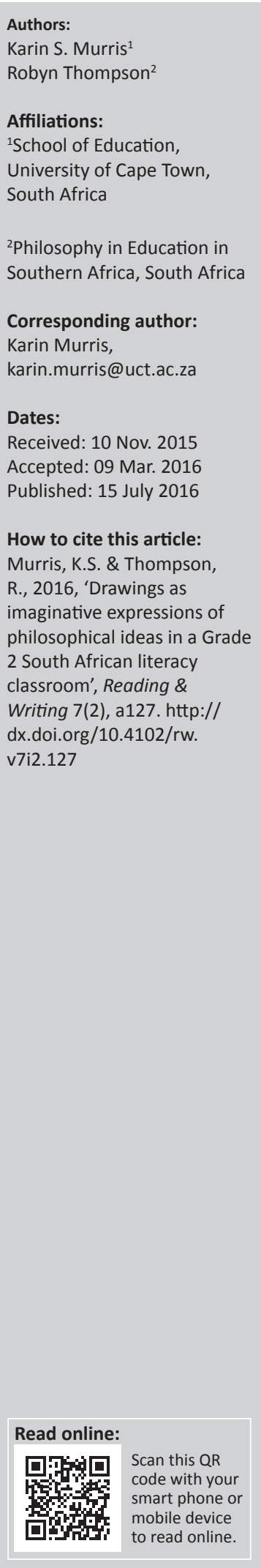

This article reports on a philosophy for children (P4C) literacy project in a South African foundation phase classroom that introduces an important new focus in the P4C classroom: the visualisation of philosophical ideas provoked by the picture book The Big Ugly Monster and the Little Stone Rabbit (2004) by Chris Wormell, giving voice to young children's own imaginative ideas and beliefs (in this case about death). This research shows how a particular use of the community of philosophical enquiry pedagogy combined with the making of drawings necessitates a rethinking of what 'voice' means. We conclude that the children's drawings bring something new into existence, thereby offering unique material and discursive opportunities for all children, including those who otherwise might not have expressed their ideas.

\section{Introduction}

In this article, we report on an early literacy research project that focused on how young children respond philosophically ${ }^{1}$ - not artistically, or psychologically ${ }^{2}$ - to a carefully selected picture book. Our findings show how the young children used drawings to create imaginative theories and beliefs (in this case about the concept 'death'), and discuss how some of the research findings changed how Robyn regarded the cognitive abilities of some of her learners in class and made us rethink what we mean by 'voice' in the classroom.

This practitioner research is positioned in a field known as philosophy for children (P4C), and traditionally, its 'community of enquiry' pedagogy uses mainly oral communication in a pedagogical tradition known as 'Socratic' (Fisher 2001). Named after the ancient Greek philosopher Socrates, the role of the teacher is that of a midwife, 'to help others bring to birth their own ideas' (Lipman 1991:202). Importantly, the enquiry mainly proceeds though oral dialogue, not through writing or drawing. In a circular seating, children think together and construct new meanings, for example, in a literacy lesson they generate and explore their own questions when reading a picture book together - aided by the teacher as guide and co-enquirer. These picture books are carefully chosen to provoke puzzlement and the deliberative semiotic 'gap' between word and image (Nikolajeva \& Scott 2000), inviting young readers to engage in a range of embodied activities, such as giving reasons, expressing opinions, agreeing and disagreeing with peers and constructing their own arguments - thinking about activities that are key to comprehension (Haynes \& Murris 2012). Importantly, such an opportunity for interrogating texts includes, but also moves beyond, the comprehension type questions typically asked by teachers, such as 'what happened in the story?' or 'what is the moral of the book?'. This Socratic approach to teaching and learning draws on the imaginative thinking of both teacher and child, as neither knows the answer to the philosophical questions the children develop together.

In this article, we limit ourselves to the discussion of drawings made by Robyn's Grade 2 class during a series of P4C literacy lessons. Previously, Robyn had been experimenting with drawings as part of her regular $\mathrm{P} 4 \mathrm{C}$ sessions and she had been struck by the richness and diversity of the drawings, in particular by some children in her class, those who usually do not speak at all. Concerned about the limitations of the traditional P4C format she speculated what the material and discursive force of objects such as paper and pencils made possible for her learners opportunities to philosophise through the visual. Part of the aim of her research was to find evidence for her initial hypothesis that making drawings can offer unique opportunities for children to create their own imaginative theories and ideas about a text, which is different from how art is 1.In a philosophical approach, art is used to express a process of thinking (with no particular concern for the product or representational qualities).

2.We were more interested in children's philosophical ideas about the concept 'death', than their feelings about deaths, as events in their lives; although the two are not disconnected, as the anecdotal can serve to illuminate more abstract investigations. 
generally used in schools. She combined the community of enquiry method of P4C with a visual research method (Thomson 2008) and inspired by the Reggio Emilia approach to education (Malaguzzi 1998; Rinaldi 2006).

We start by offering a rationale for this practitioner research project in the context of current literacy teaching and policy in South Africa and introduce Reggio Emilia's metaphor of The Hundred Languages to make a case for the importance of the visual in meaning-making, not just for some but for all children. We then continue with an overview of P4C as the conceptual framework for both Robyn's teaching and her research design. After a justification of the use of one particular picture book as the key text for the educational intervention, we focus in more detail on the research site and describe how the philosophical work in the P4C lesson generated children's own questions and drawings that surprised us. Drawing on Deleuze and Parnet, Bronwyn Davies (2014:6) describes such an encounter with data as 'an intensity. A becoming that takes you outside the habitual practices of the already known'. Maggie MacLure (2013:661) talks about data that 'glows', invoking, what she describes as 'something abstract or intangible that exceeds propositional meaning ... decidedly embodied [and] material-linguistic'. Before exploring the drawings we explain the theoretical framework and focus on the concept of voice - as explored in justifications for the use of visual research methods (Thomson 2008) and also add an ontoepistemic reconfiguration of voice, which moves beyond a focus on self.

\section{Early literacy in South Africa}

Despite substantial investment in education made by the South African government over almost 20 years, many children in both independent and government schools are still failing to achieve basic literacy and numeracy skills in the foundation phase ${ }^{3}$ (National Education Evaluation \& Development Unit [NEEDU] 2013). Learners experience great difficulty in comprehension and creative writing, which require thinking and reasoning skills (Howie, Venter \& Van Staden 2006). The low literacy results have contributed to a radical change in the national curriculum - a move from Outcomes Based Education (Curriculum 2005) to the Curriculum Assessment Policy Statement, or CAPS in short (Department of Education [DoE] 2011). The rationale for the research intervention was located within these new curriculum demands. However, the objective of the project was not to find evidence of philosophy with children in improving literacy outcomes, or to justify the use of P4C for the teaching of literacy (see elsewhere, Murris 2009) but on the benefits of using drawings to create imaginative philosophical ideas about stories as part of the teaching of comprehension. The practice was also inspired by the Reggio Emilia approach to education. Based on similar democratic and egalitarian principles, these two philosophies of education reinforce each other (Murris 2016), creating what

3.In South Africa, the foundation phase ranges between ages 4 and 9 (Grade R-Grade 4).
Karen Barad (2007) calls a 'superposition'. One compelling justification for the use of the visual is that so many South African learners speak other home languages ${ }^{4}$ than the language of instruction (mostly English ${ }^{5}$ ). But our motivation includes and also moves beyond notions such as social justice and equity. We were also interested in Reggio-inspired practices that include other 'languages' than reading and writing and involve a profound ontological and epistemological shift that includes the material (including our own bodies) and the environment in knowledge production. Italian educator and philosopher Loris Malaguzzi, founder of the Reggio Emilia approach to early childhood education, famously expresses a new concept and theory through his poem The Hundred Languages. The metaphor not only credits children and adults 'with a hundred, a thousand creative and communicative potentials' but also offers a 'strategy for the construction of concepts' and is 'a declaration of the equal dignity and importance of all languages, not only writing, reading and counting' (Rinaldi 2006:175). The beautiful poem ${ }^{6}$ laments how children have a hundred languages, but school and culture have stolen ninety-nine; they have separated the head from the body and demand from children that they think without hands. The metaphor refers at a practical level to the introduction of material-discursive tools for meaning-making in schools, such as visual arts, physical movements, videos, digital cameras, augmented realities and computers. Rinaldi (2006:192-193) speculates that even Malaguzzi himself might have underestimated the profundity of the concept. The claim he makes is that all languages carry the same epistemic dignity; that is, each language can play an equal role in knowledge production. Furthermore, they communicate with each other, interconnect, and support the conceptualisation and the dignity of the others (Rinaldi 2006). Concepts are deepened by switching languages (Vecchi 2010). The physical properties of the material of various media influence how a concept can be expressed, for example, by the use of string, blocks or clay to express a concept such as 'love' (Forman 1994:37-38). When drawing children might discover 'gaps' in their knowledge and have to readjust the theories (Forman 1994), thereby continuously building on and refining earlier thinking. Each transformation generates something new, making the situation more complex, making understanding more precise. By drawing, for example, learners get rid of excessive, superfluous or misleading ideas: 'With each step, the child goes farther and higher, as a spaceship with several stages, each pushing the rocket deeper into space' (Malaguzzi 1998:92). A drawing needs to be able to communicate; learners need to make their ideas visible to others in a much simpler, more direct way. Thus, different languages interact with one another and create new understandings in the process. The imagination is part of the

4.South Africa has 11 official languages.

5.Although schools are under pressure by the government to use mother tongue instruction in the foundation phase, many schools are under pressure (e.g. by parents) to use English for instruction because the assumption is that it will parents) to use English for
maximise job opportunities.

6.See, for example, www.ganmalibu.com for the full text of the poem. Accessed 08/03/2016. 
cognitive process here by expressing what is not there, sometimes in $2 \mathrm{D}$, other times in $3 \mathrm{D}$. This process does not only do justice to the material that plays a role in teaching and learning but also involves justice of an epistemic kind: children are positioned as rich, resourceful and resilient meaning-makers. This figuration of child is not only central in Reggio-inspired practices but also in P4C.

\section{Philosophy with children}

Philosophy with children (P4C) is an approach to teaching and learning pioneered by American philosopher Matthew Lipman (Lipman 1991). At its heart is the community of enquiry pedagogy that can be used to teach literacy (Fisher 2001; Haynes \& Murris 2009, 2012; Murris 2014) as well as a way of listening to children's own ideas about stories, hence an effective method for data collection. It can be defined as a practice of collaborative dialogue that engages a group of people in a more democratic search for conceptual understanding with a commitment to share perspectives, listen responsively and build on each other's ideas. ${ }^{7}$ The pedagogy helps to achieve important literacy goals such as developing critical and creative reading skills. In P4C, children set the agenda of a literacy lesson by asking questions about a text. It is the search for answers to their own questions that is the dynamic of the enquiries that follow. Teachers need to listen to these conversations in order to ask follow-up questions and are therefore more likely to hear what children 'think for themselves' (a goal of P4C) rather than what they might say to please the teacher as a researcher. Hence, the choice of $\mathrm{P} 4 \mathrm{C}$ for this research as it, arguably, generates more authentic data.

Bleazby (2012:96) argues that the aim of the community of philosophical enquiry pedagogy is to develop an imagination that is intelligent, and describes a typical P4C lesson succinctly as follows:

A typical P4C class involves the shared reading of a narrative, containing philosophically puzzling ideas, followed by a classroom dialogue initiated by student questions and responses to the text. Through formulating questions, articulating problems, defining concepts, constructing solutions, expressing opinions, providing reasons, and evidence, constructing criteria, searching for counter examples and evaluating arguments and ideas, students aim to reconstruct philosophical problems and, in doing so, make sense of their world. This process necessitates, as well as scaffolds, the development of intelligent imagination.

Drawing on John Dewey, Bleazby explains that the role of the imagination is central to reasoning about texts. The imagination is needed to draw on past experiences, to conceive of alternatives to problematic situations, to 'suggesting means to reach those ends' and 'evaluating those means through considering their possible consequences' (Bleazby 2012:98). In short, through the imagination we can move beyond the here and now and imagine other possible ways of doing things - possibilities that also can be realised (Bleazby 2012:99). Understanding and transforming reality seem to go hand-in-hand, because for Dewey the imagination also enables moral reasoning with its obvious connection to empathy (Bleazby 2012:101). Empathy requires a form of thinking that imagines other ways of seeing, thinking and doing - key to the teaching of comprehension. Children's literature offers rich opportunities for readers to put themselves metaphorically into the shoes of fictional characters across time and space (Murris 2009).

\section{Reading picture books philosophically}

Print-based texts and 'illustrated stories' dominate the standard reading resources in South African schools. Images in such stories function to help young readers decode the written words. Therefore, they aim for the least possible ambiguity between word and image. Such graded readers are very different from the many ambiguity-rich, complex picture books that are now available and ideal for the imaginative meaning-making activities central to $\mathrm{P} 4 \mathrm{C}$ (Haynes \& Murris 2012). In addition to using the textbooks and graded readers - regarded by the government as part of the solution to the current literacy crisis (as described in NEEDU 2013) - Robyn decided to work also with picture books in her own Grade 2 class. Useful multimodal texts for the foundation phase classroom, they draw on 'multiple modes of expression' (Serafini 2009:11). They are short stories that engage the imagination and emotions (Haynes \& Murris 2012), can be read in a short space of time and are accessible to a wide range of learners.

In picture books, the meaning of the two different sign systems (the written and the visual) is far from fixed. There are not only two different languages or sign systems - the words and the images (Lewis 2001) - but the graphic design also helps to tell a story (Serafini 2009:11). In semiotics, ${ }^{8}$ there are also infinite sub-sign systems, for example, use of colour, place on a page (Doonan 1983), choice of art style ${ }^{9}$ (Browne \& Browne 2011) and the shapes. How these signs 'interrelate, connect and influence each other' depend on what children themselves bring to the narrative. The particular materialdiscursive characteristics of these 'highly sophisticated aesthetic objects' (Sipe 2012:4) make room for children's own voices. The teacher's role in P4C is crucial in modelling openended philosophical questioning - especially the kind of second-order questions ${ }^{10}$ that follow on from children's questions. So the teacher needs to listen carefully and respond to what is happening in the moment, for example, when children talk about their drawings. This is very different from the activity of asking children to draw a scene on the basis of something that looks fun to them (e.g. in Soundy \& Drucker 2010:450), or what they like or dislike. In a philosophical use of children's drawings, the teacher focuses on the contestable meanings of the abstract (philosophical) concepts embedded

$8 . S e m i o t i c s$ is the study of signs and sign processes and the shared and shifting meanings attached to them.

9.See in particular Browne's fascinating autobiographical reflections on his choice of art styles for his picturebook Little Beauty (Browne 2011:218-224).

10.See footnote 6 
in their questions and expressed visually. For example, when children are puzzled about Jack's actions in the fairy tale Jack and the Beanstalk, the children's questions will inevitably lead to the making of drawings about the meaning of concepts such as 'big', 'good', 'evil', 'strong', 'brave', 'risk', 'trust', 'honesty', 'danger', 'death', 'wealth', 'greed' and 'protection'. Although personal responses and anecdotes are encouraged and the connection with children's own experiences and ideas are a necessary condition for analysing the meanings of these concepts, children's responses (including drawings) are also critically compared and evaluated by their peers. The enquiry process focuses more on an examination of the justification given for the answer than on the answer itself, and in the process the reasoning skills for comprehension are developed.

\section{Visual research methods and voice}

The use of drawings is gaining increasing attention in social sciences research as an alternative representational resource to talking and writing (Mavers 2011; Mutonyi \& Kendrick 2011), for meaning-making through the arts and visual literacy (Hopperstad 2010; Soundy \& Drucker 2010) and for visual research (Clark \& Moss 2011; Thomson 2008). The dominance of the spoken or written word in literacy research (Kendrick \& McKay 2009:54) has meant that children's own drawings are often undervalued and underexplored as part of cognitive meaning-making processes (Narey 2009; Soundy \& Drucker 2010). In contrast, researchers such as Kendrick and McKay (2009:54) draw on recent research that demonstrates that children are able to express powerful and imaginative ideas and problems through visual modes'. They argue that 'children draw to know, that is, drawing is one way that children create and express complex meanings about their world' (Kendrick \& McKay 2009:53). In a sense, the arts are 'an essential component in children's ability to make meaning of their world' (Whitfield 2009:156).

Despite this trend, social sciences research still relies heavily on numbers and words. The use of images opens up powerful ways of seeing and knowing, and is more likely to 'elicit raw emotions that cannot readily be expressed in words' (Cox et al. 2014). However, a philosophical analysis of drawings does not focus on what the visual represents but on the new that is produced through the drawing activities. Therefore, the key question that guided our analysis is how do the drawings produce new philosophical theories and concepts that matter to the children?'

From a research ethics point of view, drawings for data collection in early childhood education are highly encouraged as visual media are regarded as being more child-friendly and more likely to express what children really think (Clark \& Moss 2011; Thomson 2008), although Thomson (2008:3) stresses that there is no such thing as an 'authentic' voice. She reminds us that '[p]ower relations of class, gender, race, ethnicity, disability, sexuality and age all constrain social relations and limit profoundly what can be said ... as well as how it is heard' (Thomson 2008:6). She points out the clear advantage in using visual methods (for collecting richer research data) and argues that drawings are the product of specific adult-child relationships and interactions in time and space and that '... the notion of voice suggests both a particular point of view and also one that is not universal (Thomson 2008:4). Children and young people don't speak as one - just like adults, they have different experiences, opinions and modes of expression'. Therefore, as a hermeneutic activity, interpreting drawings will always be partial, subjective and tentative. The ambiguity and complexity involved in analysing children's drawings might explain why they are used mainly for artistic expression (not for interpretation or as a cognitive meaning-making tool) or to support writing (emergent literacy) in schools. Most teachers feel out of their depth (Soundy 2012).

Drawing on Britzman, Thomson (2008:4) explains the three different meanings of voice (generally speaking: 'having a say'): the literal (speech and perspective of the speaker), the metaphorical (qualities and feelings conveyed by the speaker's words) and political (the right of speaking and being represented). We used these ideas to analyse the data.

\section{The research project}

\section{The research site}

The research site (Robyn's own class) was a foundation phase Grade 2 class consisting of 21 children at a private school on the East Rand near Johannesburg. At the time of the research their ages ranged from 7 years to 8 years, while four of the learners were 9 years old. The class was fairly evenly balanced with 11 girls and 10 boys. Of the 21 children, there was one girl of Indian descent; the others were white. The home language of 19 children was English (two Afrikaans) with English as the medium of instruction at the school. Of the 11 girls, three were on prescription medication for attention deficit disorders, while 6 of the 10 boys were on some form of medication for the same reason. These children have been identified by teachers (either in Grade R or Grade 1) as having some barrier to learning.

\section{Procedures of data collection}

Robyn conducted a small-scale research project in her own classroom. Over a period of three months, she implemented an intervention $(\mathrm{P} 4 \mathrm{C})$, collected her data through audio taping the community of philosophical enquiry sessions, transcribed the oral discussions, collected children's reflective journals and drawings, and made field notes (of her classroom observations and self-reflections).

\section{The philosophy for children process}

The planning and running of a $\mathrm{P} 4 \mathrm{C}$ session are very different from a more conventional literacy lesson. The children were seated on chairs in a circle, not behind desks or tables, so that everyone could hear and see each other. Robyn also sat in the circle but she had a different role in that she did not ask the children questions about the text - after the picture book had 
been read aloud. Instead, she collected their questions by writing them down on a flipchart after an exchange of ideas in pairs. In order to give learners enough time to formulate good questions about the story, they were given 'thinking time'.

During this 'thinking time' - a time especially created for private and quiet reflection just after the story had been read aloud - the children were encouraged to draw ${ }^{11}$ their thoughts and questions about the story, without copying the images in the book. They were asked to record their initial feelings, thoughts or ideas about the story, and it had been made clear to them that their drawings did not have to be completed artworks but functioned as a meaning-making tool. The children were reminded that usual requirements such as spelling, neatness and colour were not important, but that individual expression mattered most.

Thinking time was followed by a community of enquiry whereby Robyn's role was to ask mostly probing open-ended philosophical questions in response to their own questions and their efforts to answer the questions they had chosen themselves. Finally, children were given ample opportunities to make their own drawings as an essential part of the construction and communication of knowledge about the questions that had been raised in the enquiry and that were of importance to them.

\section{The picture book: The Big Ugly Monster and the Little Stone Rabbit}

Robyn had chosen a picture book for this project with the idea in mind of stimulating their 'imaginative intelligence' (Bleazby 2012). The children had not seen or heard it before. In particular, she wanted to record the children's responses to the 'gap' or space that the artist Chris Wormell had created intentionally between words and images in his book, The Big Ugly Monster and the Little Stone Rabbit (2004). In this story, a lonely monster (Figure 1) is so ugly, that nature shrivels up and dies, animals run away and even stone crumbles to dust.

There is one exception, however: a small stone rabbit which becomes the monster's inseparable friend. They are happy together for a long time, until one day we see the monster wandering into his cave, never to come out again. The rabbit sits outside and waits.

Adults usually understand this page as signifying that the monster had died, but the children in Robyn's class looked puzzled and expressed uncertainty about the fate of the monster, so Robyn suggested that they could draw the inside of the cave. Put differently, the drawing activity was an opportunity to listening to children's own ideas.

\section{The community of philosophical enquiry}

The data for analysis were all the children (nine) who contributed orally in the community of enquiry. Moreover, Robyn had P4C sessions.

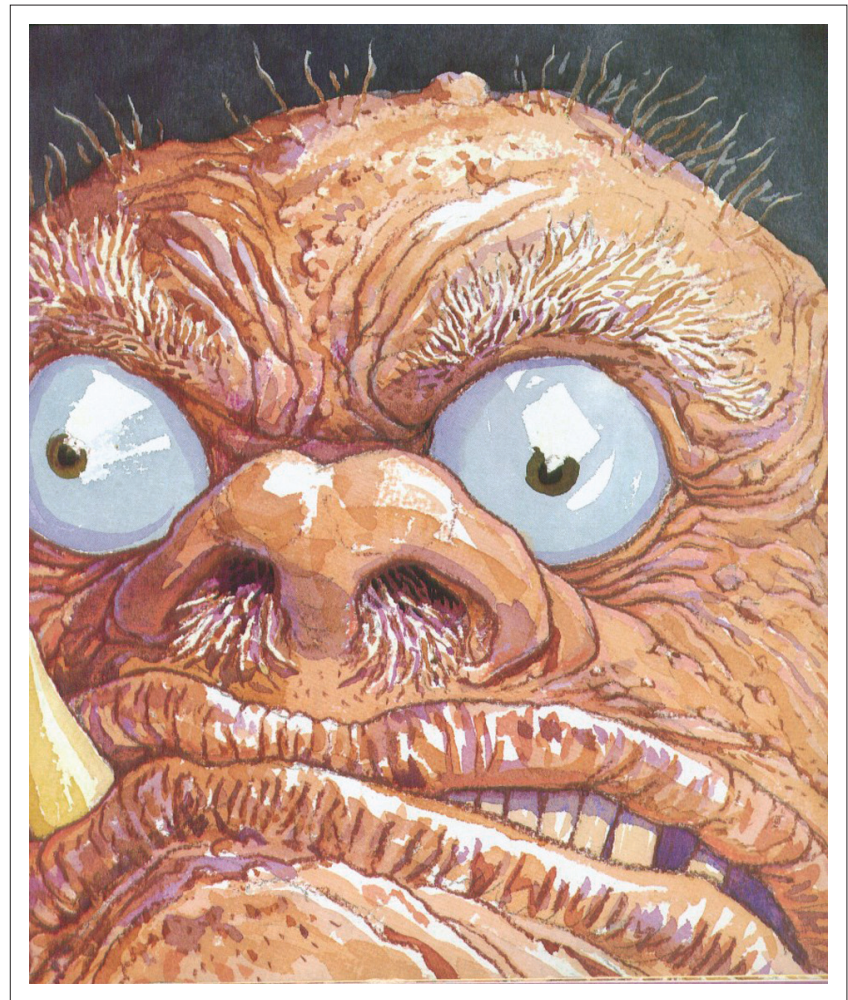

Source: Wormell, C., 2004, The big, ugly monster and the little stone rabbit, Random House, London

FIGURE 1: The big ugly monster.

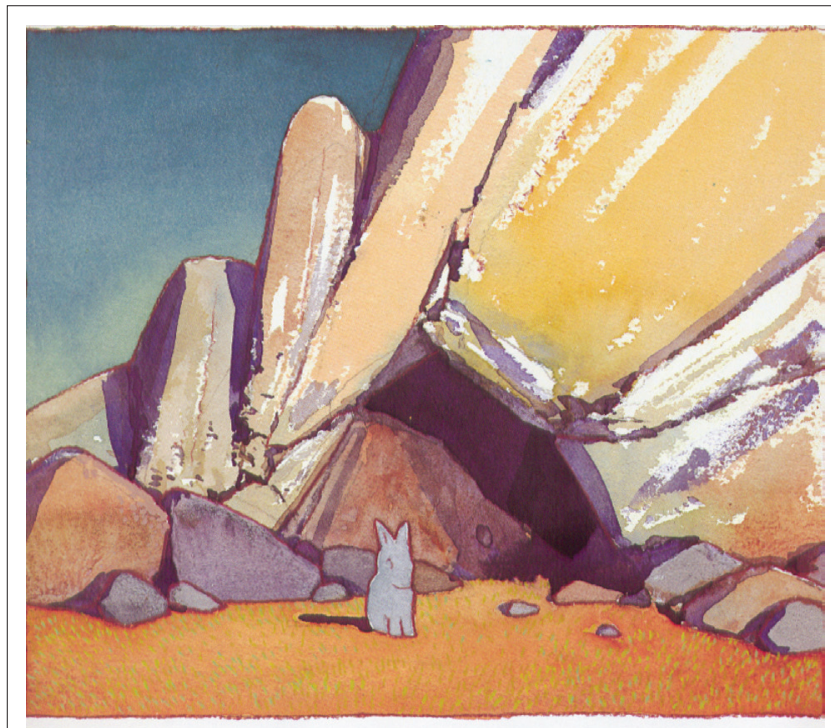

But one day the monster never came out of his cave and the stone rabbit sat alone.

Source: The Big Ugly Monster and the Little Stone Rabbit (2004) FIGURE 2: The rabbit sits outside and waits.

conversations with seven (other) children as they were making their drawings. She recorded these conversations as field notes. The subsequent analysis of the drawings was related to two of the philosophical questions asked by the children following the reading of the story: 'Is the monster dead or alive?' and 'How do 
we go to heaven?' Robyn's research aim was to find out how children who had been silent in the enquiry could participate visually through their drawings and add new meanings. Later on, during the project, she became increasingly intrigued by the children's interpretations of the monster's 'disappearance'.

\section{Findings: The data that 'glowed'}

There was a much greater diversity of ideas about the concept 'death' in the visual material than had been expressed orally, as evidenced by the transcripts. Also, all children had made drawings, whereas only about less than half had participated orally. This is an important social justice reason for including drawing routinely in all $\mathrm{P} 4 \mathrm{C}$ sessions, and not just in the early years.

Moreover, as typical of the self-reflexive dimension of research, Robyn had noticed how she had come up against her own expectations of a couple of boys with barriers to learning. She had not expected them to be able to cope with the intellectual demands of the philosophical tasks. Hence, at the end of our analysis, we finish with a commentary on Robyn's role as teacher. But first we present the two questions the children raised and emerged as significant topics for the children judging from the joint examination and discussion of the children's drawings and the field notes made by Robyn.

\section{Question 1: Is the monster dead or alive?}

As adult readers, we had assumed that the monster in this story had died in the cave. Some children had indeed drawn pictures with the dead monster in the cave (see Figure 3). However, we were very surprised to see also drawings with monsters that were still alive (Figure 4).

It soon became obvious to us that the children had struggled to communicate visually what a dead body looks like as opposed to a body asleep. This is not surprising, as seeing a dead body is not experienced often and/or by everyone (Figures 5 and 6).

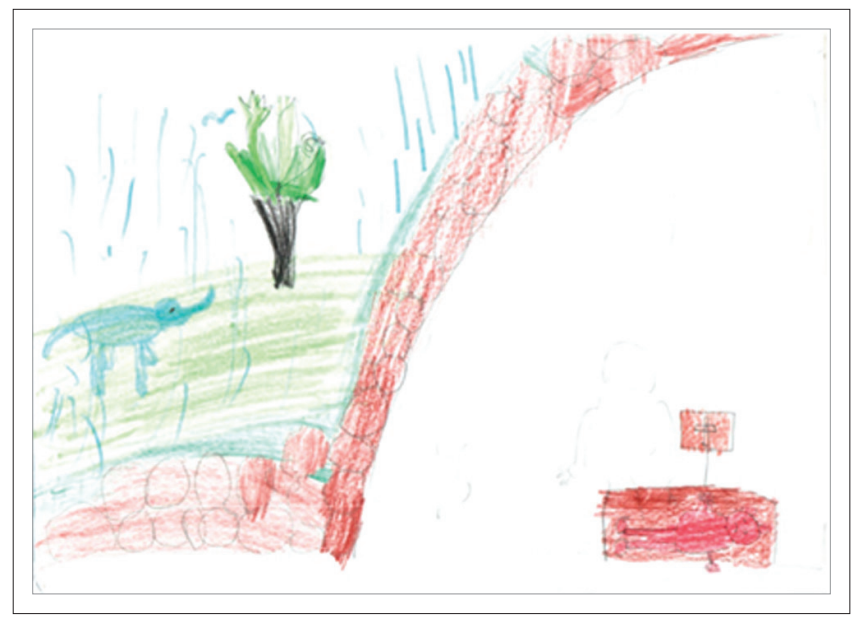

Source: Provided by author

FIGURE 3: A drawing of the dead monster in his cave.
Both these children had expressed how the story connected with their own life experiences; they both had different explanations for their drawings. Chris ${ }^{12}$ (Figure 5) explained:

'This is the way you draw dead eyes. I have seen this in cartoons. If you are dead, this is what it looks like.' (Male, aged 8)

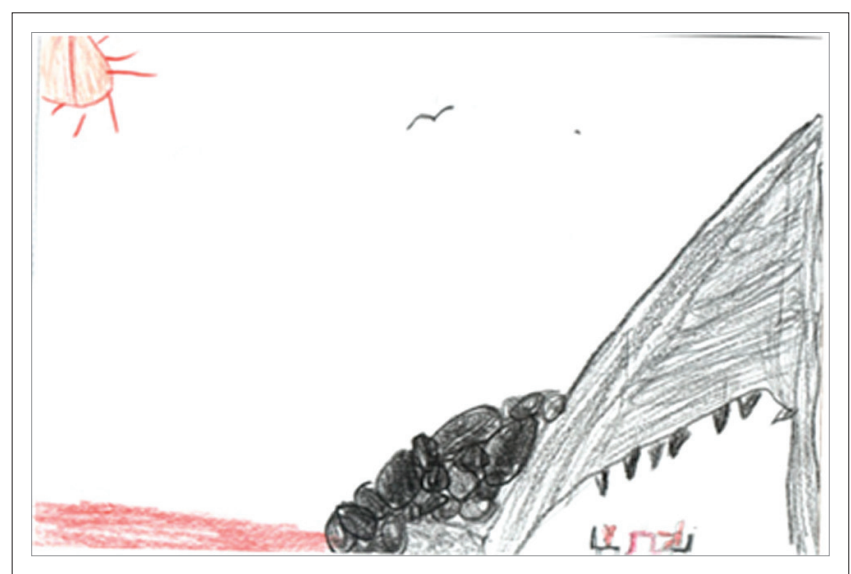

Source: Provided by author

FIGURE 4: A drawing of the monster and the rabbit alive in the cave.

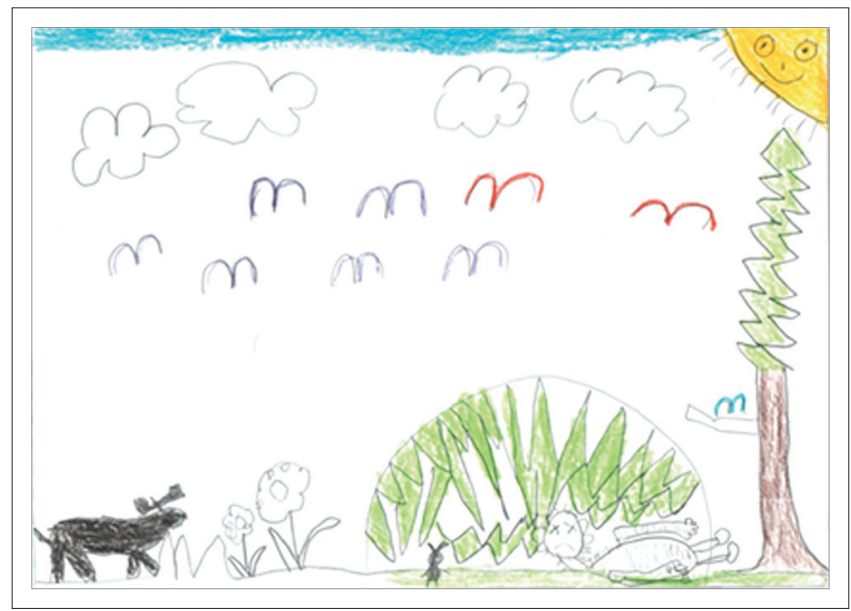

Source: Provided by author

FIGURE 5: Is the monster dead or asleep?

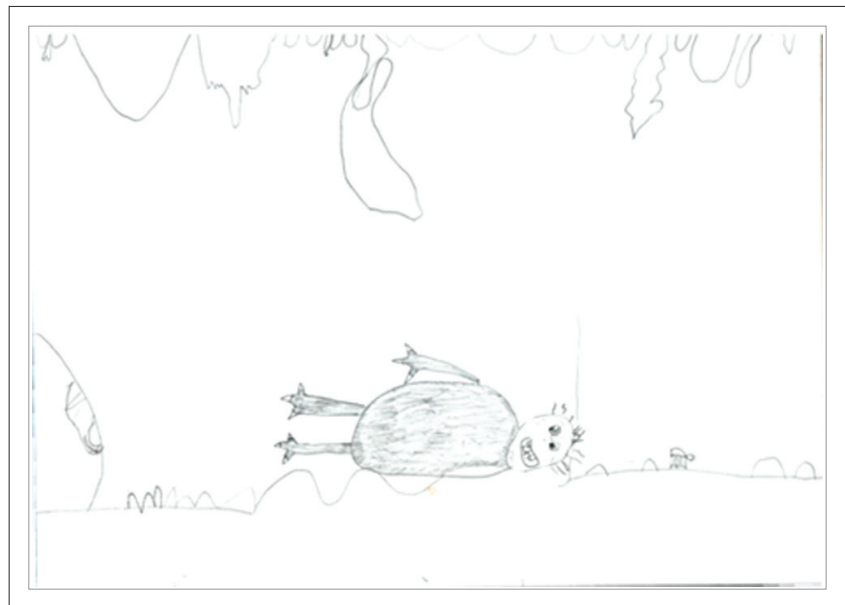

Source: Provided by author

FIGURE 6: Is the monster dead or alive?

12.The children were indeed boys, but we have used pseudonyms. 
You can't have eyes open to look' (Field notes, 2012). While Alvin proposed that:

'Sometimes you die so quickly, you don't have time to close your eyes.' (Male, aged 8) (Field notes, 2012).

When putting all the drawings together we noticed how different the children's ideas were about the inside of the cave, and how in the material-semiotic act of drawing the children had created something new. Many of their drawings subverted the 'correct' meaning of this particular page 'in' the book, that is, that the monster died of old age inside the cave. Their imaginative intelligence had been made visible in their drawings by producing other possible readings of the text.

Furthermore, the community of philosophical enquiry sessions had also made it possible for the children to go 'beyond' the story and speculate about the technicalities involved in the afterlife. These were manifested in visual answers as expressed through the drawings.

\section{Question 2: How do we get to heaven?}

During 'thinking time' (the time for private reflection after the story has been read), many of the children had drawn pictures about death; about what happens when we die and how we get to heaven ${ }^{13}$ - assuming there is one. It could be argued that talking about a concept such as heaven might silence the children who do not believe in heaven, for religious, cultural or other reasons. In P4C, children raise the topics for enquiry, even when uncomfortable or judged as inappropriate by adults facilitating or observing. The community of enquiry is a rare classroom space where children are allowed to participate in making decisions about the content of a lesson through democratic procedures (Haynes \& Murris 2012). As stated before, the pedagogy positions children as rich, resilient and resourceful, not as fragile, vulnerable and in need of protection by an adult who is an epistemic authority, that is, knows better and best what children need, which is a form of onto-epistemic injustice (Murris 2016). Simply by virtue of being child (onto), young people are discriminated against because of their age and judged to be epistemically inferior. But children have their own philosophies that offer something new to the pool of ideas as Robyn's research suggests. Many of the children positioned heaven as a place in the sky, looking down on the world. Some also drew souls moving upwards in the sky to reach heaven. The concept of movement is difficult to express visually.

In Daniella's picture (Figure 8), an angel carries the body of her grandfather while the 'powerful and strong' God watches. Her idea that souls get to heaven by being carried by an angel is clearly shown in her drawing. It is interesting that for her the burning gets rid of the flesh, but not the bones, and that the soul is like a ghost (like the person alive, but transparent).

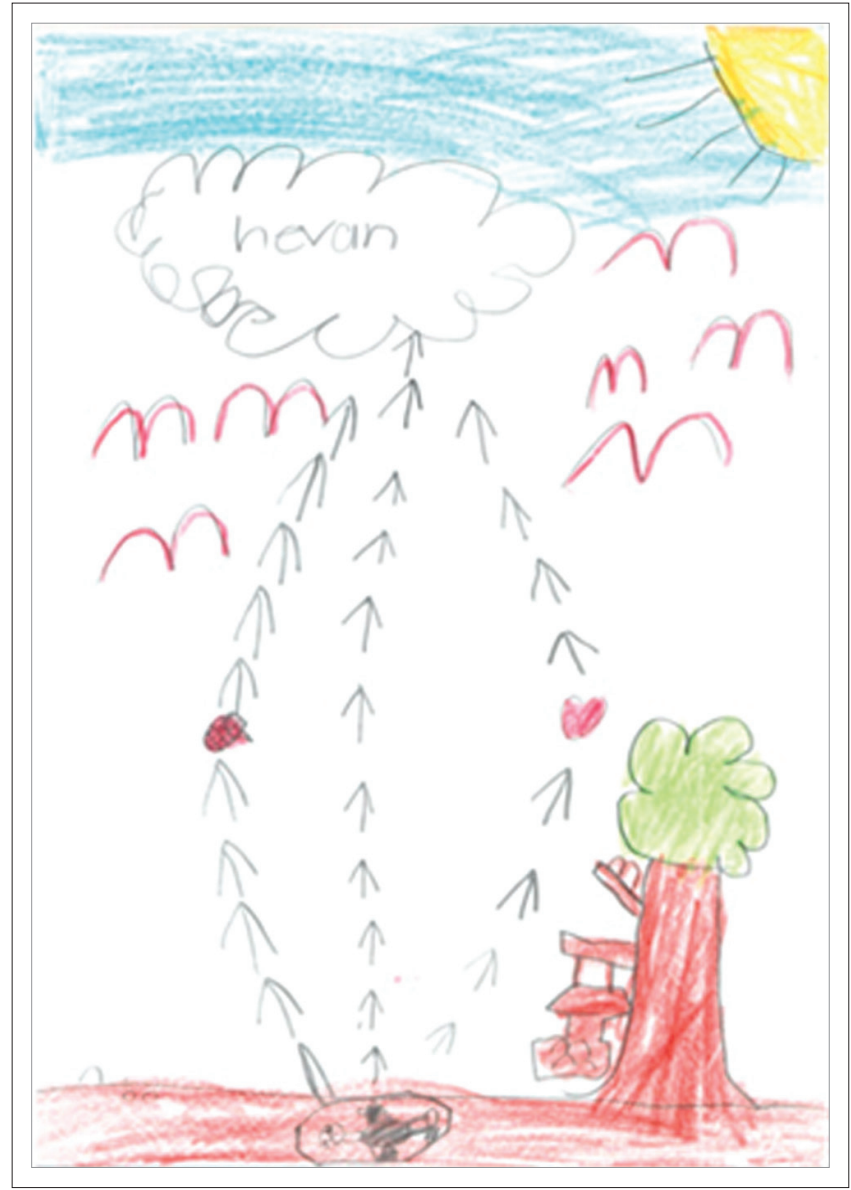

Source: Provided by author

FIGURE 7: Chris's theory of how we get to heaven.

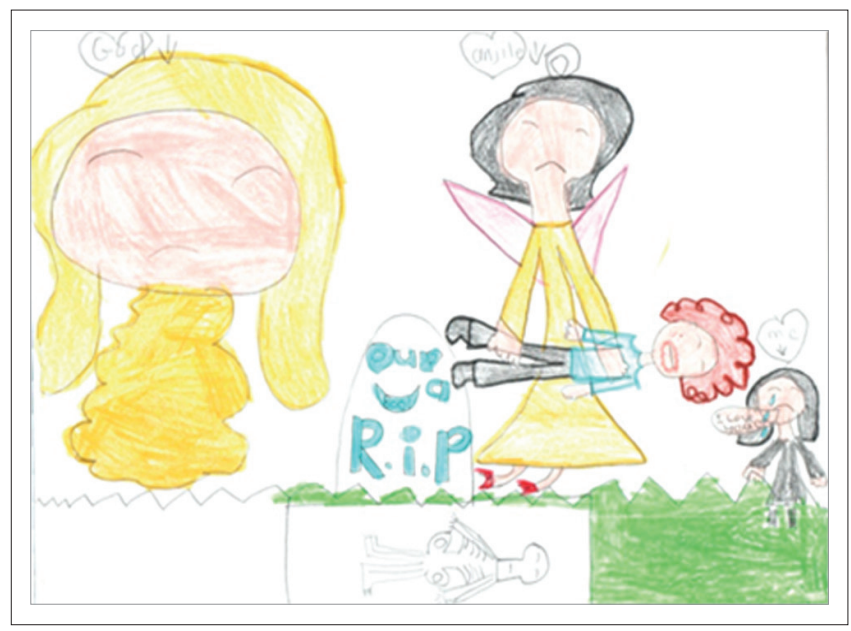

Source: Provided by author

FIGURE 8: Daniella's theory of how we get to heaven.

Chantel's (female, aged 8) answer to the question 'How do we get to heaven?' involves an intricate pictorial representation of a staircase made of clouds that lead up to heaven. She had drawn two distinct pathways signposted ' $G$ ' for God and 'A' for angels and the deceased (Figure 9).

The drawing shows the importance of God for Chantel, because he is entitled to his own staircase. 


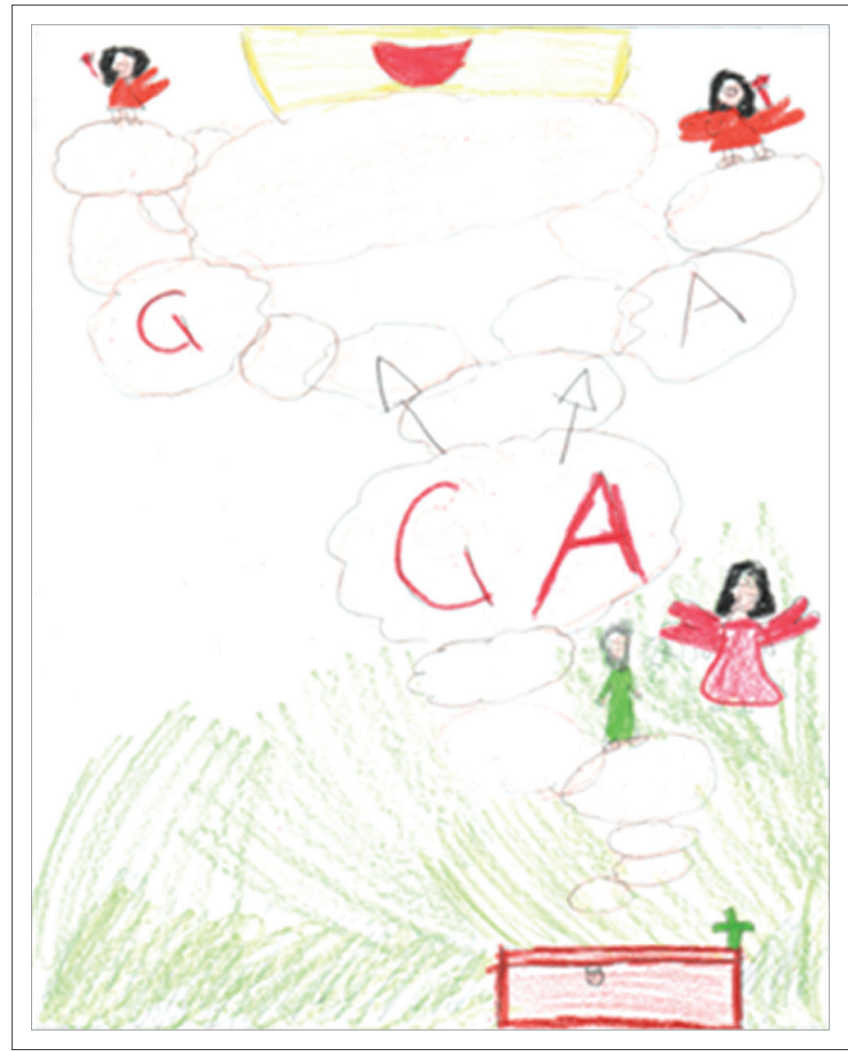

Source: Provided by author

FIGURE 9: Chantel's theory about how we get to heaven.

The children expressed their own ideas in various ways. Kay put it as follows:

I know how our souls get to heaven. I definitely know this one, [thinking, pulls a face and purses lips]...there are flesh eating bugs, they only eat flesh. Not your skeleton - bones are hard for their teeth. They get into the box [coffin] and bite you. All your soul needs is just one hole from a bite. Your soul crawls out the hole. (Female, aged 9).

Below are four more examples of children's theorising about what happens when humans die. Each drawing shows a unique answer to the problem of how we get to heaven. We have included them, because they show how different they are as opposed to so much art work we see in schools.

In philosophical work with young children, it has been noticed before (Haynes \& Murris 2012) how eager many children are to discuss the topic of death, and also how imaginative and thought-provoking their ideas are. Robyn's research showed how the addition of the visual includes even more children. Also, the ideas expressed by the children about this particular moment in Wormell's picture book confirm findings reported elsewhere (Haynes \& Murris 2012:132-136) that children do not accept the adult 'gapfilling' between image and words (Figure 2). Interestingly, if the typical use of rhetorical ${ }^{14}$ comprehension questions in schools (e.g. 'What happened in the cave?') would have been used in this literacy lesson, 'the' ending of the story would not have been an open question, worthy of examination and 14.To rhetorical questions, teachers already know the 'correct' answers. philosophical exploration. What would have been missed is the possibility of considering that the monster is still alive as the correct answer, or arguably that staircases exist that help souls to ascend to heaven.

\section{Teachers' expectations of children as thinkers}

An important aspect of practitioner research is the teacher's reflective process. Through carrying out the research Robyn's 'taken-for-granted' thinking about some of the children in the class was disrupted. As discussed above, a number of the children in this class were on medication and usually struggle to write their ideas down. Robyn observed how engaged they were this time with their drawings and wondered if this had been made possible because they were allowed to express their ideas visually. She also observed how her own attitude changed towards one particular child with barriers to learning as a direct result of the drawing activities and our discussions during the research process as we explain below.

On the left-hand side, there is a domestic scene with tables, chairs, a television, the rabbit and the monster - alive. To the right of the monster is an arrow, pointing to a 'second' monster lying on the floor. The latter is separated from the first by a continuous zigzag line. There is no colour used in this portion of the picture. Whilst this monster has circles for eyes, his mouth is an irregular line, almost a painful grimace. The lack of colour and the grimace of the mouth could indicate that perhaps this monster is dead.

Usually, a quick glance at the picture would have led Robyn to conclude (perhaps with some irritation) that, as usual, there was no neatly coloured-in picture. Moreover, the child, Garth (male, aged 9), had drawn two monsters instead of one. Surely this was incorrect as there were not two monsters but one in the book. However, when Robyn looked more closely a complex representation of ideas became apparent to her. Viewing the picture (Figure 11) from left to right, there is a dynamic movement in the picture itself. The arrow clearly leads the viewer's eye from a representation of the live monster to the dead one.

In the next drawing, Neil (male, aged 8), who sat next to Garth, had also drawn a detailed picture showing the inside of the cave (Figure 12). There are many similarities between the two boys' pictures, which include the positioning of the picture on the paper, the entrance to the cave, the inside of the cave, the furniture and even the monster is similar in the way the body is drawn.

The entrance to the cave is blocked by pebbles, shown by repetitive small circles and an arrow showing the way in. When Neil had first heard the story and seen the pictures, he was convinced that there were more rocks at the entrance of the cave at the time of the monster's death than at the beginning of the story. This intense engagement in 


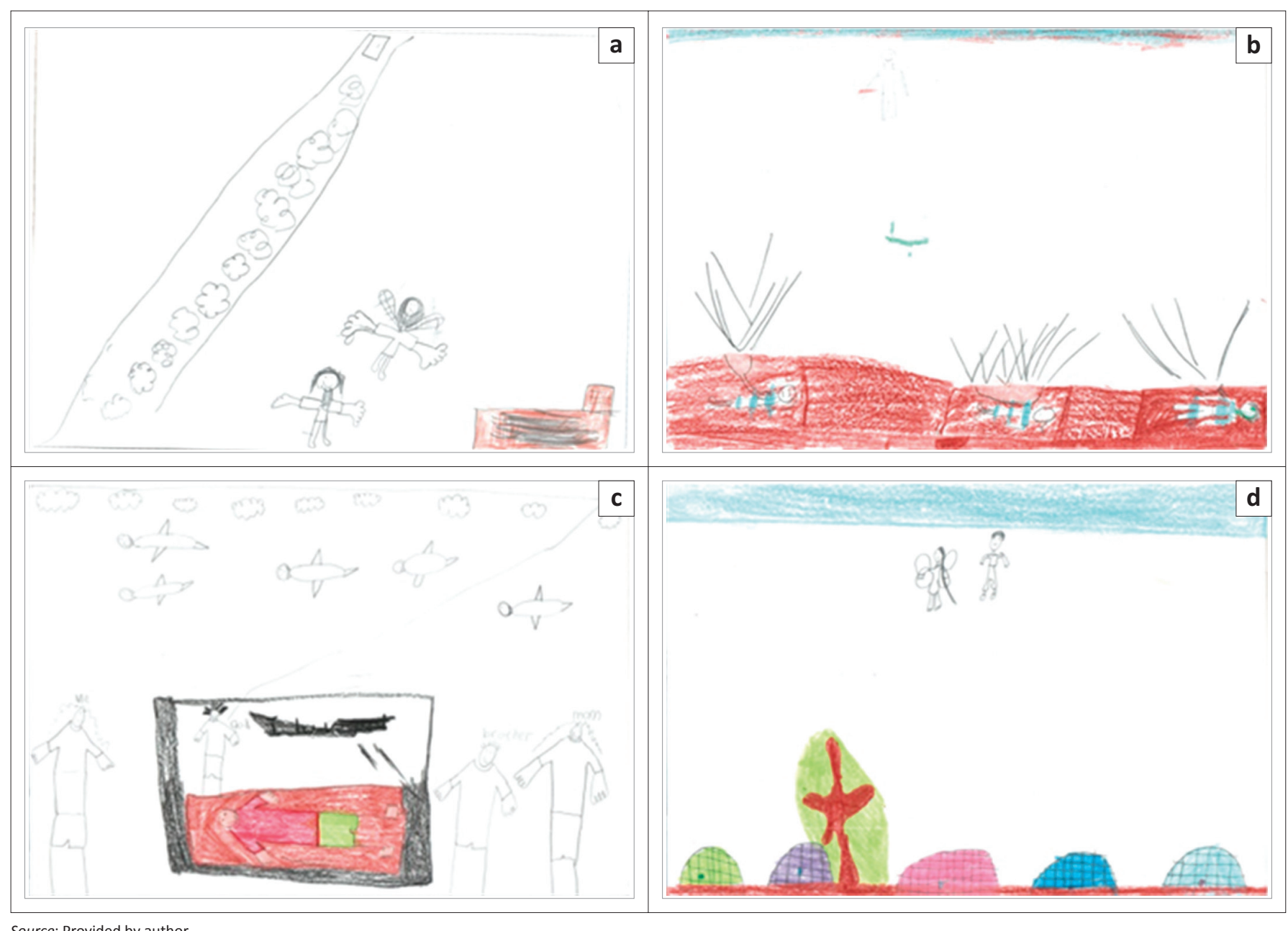

Source: Provided by author

FIGURE 10: More theorising about how to get to heaven (a-d).

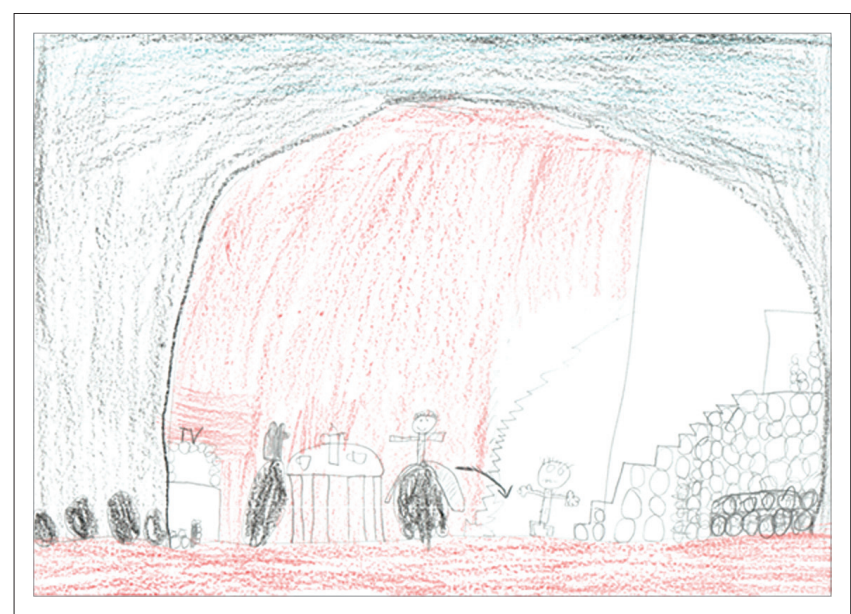

Source: Provided by author

FIGURE 11: Garth's drawing of the monster's cave.

his request to Robyn to turn to the beginning of the story and back to the last scene of the entrance to compare the positioning of the rocks in order to be certain. He then suggested that maybe the monster had died in a rock fall when walking into his cave. This idea is depicted in his drawing. It is only by listening to what Neil had to say about the picture as he completed his work, that Robyn could make the connection between his illustration of the

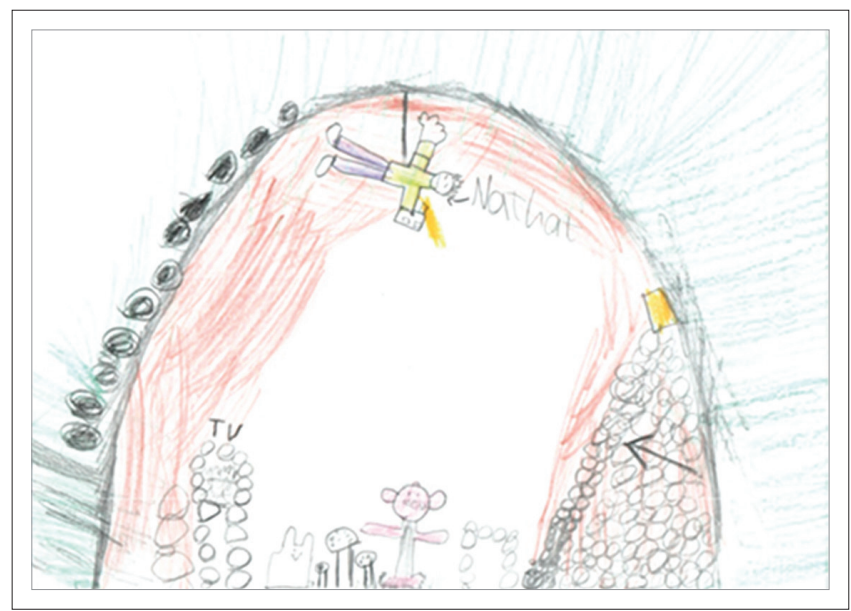

Source: Provided by author

FIGURE 12: Neil's drawing of the monster's cave.

entrance of the cave and his interpretation of the turning point in the story. Neil's drawing clearly shows the scientific hypothesis that he had used to explain the ending of the story. The hypothesis is that if a rock falls, the monster will die. A particular rock (indicated by the arrow?) must have fallen and therefore the monster is dead. His drawing weaves together personal, scientific and philosophical strands of reasoning. Robyn's attentive 
listening to Neil's explanation of his drawing had made it possible for her to regard this learner in a very different light cognitively.

\section{Discussion}

What the evidence from the drawings shows is how the critical combination of the carefully selected image in the picture book, the philosophical focus and the visual medium had made it possible for the children to generate their own imaginative questions and answers. This philosophical reading would not have been possible if Robyn had asked closed questions about the story - questions that would have assumed that the monster is dead in the cave as the correct answer.

In this project, the children had been invited to make drawings as an essential part of the cognitive and imaginative process of meaning-making in $\mathrm{P} 4 \mathrm{C}$. The drawings show clearly how the children used this medium to construct and brought something new into existence: their own new ideas about the turning point in this story, and in that sense were given a voice (in the ontological sense). The data also confirm Kendrick and May's claim that drawings give insight into spontaneous concept development, that is, into the meaning of concepts that have developed from children's own experiences (Kendrick \& May 2009:55), in this case about death. And they were developing their own theories when, for example, trying to solve the problem of how souls move up to heaven.

Important in $\mathrm{P} 4 \mathrm{C}$ is the relationships learners build with each other through responding to, and building on, each other's ideas. In this dialogical exchange new ideas are given birth out of nothing. There is no representation or repetition of what the teacher (or the author) believes what this moment in the story 'is about'. It was significant that the two boys with barriers to learning had little difficulty in having 'a voice', compared with when they have to put their ideas in writing. The drawings gave them an opportunity to 'have a say' literally, as Thomson would say, and to express their feelings. They were indeed given the political right to speak and to have their ideas represented. But for us, something even more profound happened. Metaphorically speaking, these children drew them-selves into being (through their relationships with others) - each drawing is an imprint of a child's self. Their drawings brought their ideas into being, and this ontological and philosophical orientation poses a profound challenge to psychological stage theories. Robyn's research sees pictorial production as a semiotic activity that resists psychological stage theories of art development (Kendrick \& McKay 2009; Soundy \& Drucker 2010). Kendrick and McKay (2009:60) argue that children's drawings have a 'voice' - they are an imprint of 'each child's self'. But, the communal nature of the enquiry process in $\mathrm{P} 4 \mathrm{C}$ resists regarding the drawing as products of one individual. Unlike the more standard or psychological self-concept, we propose a post-developmental concept of self (Murris 2016).
Developmental psychology focuses on the development of the individual and fixes what children are capable of through predetermined discourses and expectations. This essentialising 'devalues them by placing limits on how they see themselves, on how we see them, and on how we hear what they want to say' (Canella [2002] in Cahill \& Gibson 2012:96).

Through thinking together philosophically with others in a community of philosophical enquiry and the material affordances of the paper and pencils, the children brought into creative existence their own ideas through thinking with others in a community. We suggest using drawings as a way of 'listening' to their voices without, for example, regarding a drawing as typical of a particular developmental stage (Soundy \& Drucker 2010:448), which would imply denying the unique characteristics of the individual drawer. When the community of philosophical enquiry pedagogy is used as part of a literacy lesson, meanings are created, not transmitted, and children's drawings are included as unique expressions of 'intelligent imagination' - as a way of 'speaking' with one's own 'voice'. However, the data suggest a fourth meaning of voice. Voice, not ontologically tied to an individual body, but a voice that expresses what the community of enquiry has brought into existence. A voice that despite its individual expression, is nevertheless a communal voice, bringing some-thing new into the world, into existence in the shape of drawings. This communal voice (with individualised expression) is not a representational voice. A voice that can be substituted by anyone else in the community, but a voice that presents (brings into being) ideas that have not been expressed before (Biesta 2006, 2010). Each drawing therefore needs to be interpreted in the here and now without fixed ideas about children's universal age-related capabilities. It would otherwise prioritise essence (essentialist general agerelated ideas about childhood) over existence (the experience of what individual children in communities of enquiry as a matter of fact can do in the here and now). After all, the children had little difficulty in engaging with complex abstract concepts, such as 'heaven', 'death' and 'soul'. These concepts are not concrete, but nonetheless the drawings show that these young children engaged with them meaningfully and creatively and without any apparent sign of psychological distress. Cognitive stage theories are unable to categorise the imagination because they draw on the 'other half' of the child's intellect (Egan 1993). Creative thinking moves beyond immediate experiences and the world-as-it-is. It is this intelligent imagination that $\mathrm{P} 4 \mathrm{C}$ draws on and also fosters.

As we have seen in the introduction, philosophical enquiry in the Socratic tradition is a linguistic practice. It is grounded in listening to or reading texts (Lipman 1991) followed by oral enquiries (Fisher 2001; Haynes 2008). We have argued that P4C sessions should include drawing (e.g. during thinking time) because it offers unique opportunities for children who are less likely to contribute orally, and offers one of the other 'ninety-nine' languages to all children. 


\section{Conclusion}

Part of the aim of Robyn's research was to find evidence for our initial hypothesis that making drawings in the $\mathrm{P} 4 \mathrm{C}$ classroom can offer unique opportunities for children to show their teachers that through drawing they can read texts philosophically, and that they can speak with their own voice through the thinking with others about philosophical topics such as death and what happens when people (or monsters) die. What surprised us was the power of the community of enquiry pedagogy through the drawing activities not only to include some, otherwise more reticent children, to contribute, but also noticed how the pedagogy necessitated a fresh way of thinking about voice in visual research. Our philosophical readings of the children's drawings (in combination with their oral contributions) show that the combination of a philosophical reading approach such as $\mathrm{P} 4 \mathrm{C}$, combined with the opportunity to include drawings in the way suggested in this article, is a powerful combination for early literacy. When analysing the children's drawings philosophically, the children show diverse and original visual meaning-making of the abstract concepts embedded in the questions they explored together. Furthermore, and perhaps even more importantly, the inclusion of the visual opens up significantly more possibilities for inclusion and active participation of the large majority of African language speakers in our mainly English-speaking government and independent schools.

\section{Acknowledgements}

We would like to thank the children in Robyn's class for their participation in and permission for this research project.

\section{Competing interests}

The authors declare that they have no financial or personal relationships which may have inappropriately influenced them in writing this article.

\section{Authors' contributions}

K.S.M. and R.T. contributed equally to the writing of this article.

\section{References}

Barad, K., 2007, Meeting the universe halfway: Quantum physics and the entanglemen of matter and meaning, Duke University Press, Durham, NC.

Biesta, G.J.J., 2006, Beyond learning, Paradigm Publishers, Boulder, CA.

Biesta, G.J.J., 2010, Good education in an age of measurement: Ethics, politics, democracy, Paradigm Publishers, Boulder, CA.

Bleazby, J., 2012, 'Dewey's Notion of Imagination in philosophy for children', Education and Culture 28(2), 95-111. http://dx.doi.org/10.1353/eac.2012.0013

Browne, A. \& Browne, J., 2011, Playing the shape game, Doubleday, London.

Cahill, B.J. \& Gibson, T., 2012, 'Using critical theories in the curriculum', in N. File, J.J. Mueller \& D.B. Wisneski (eds.), Curriculum in early childhood education: Reexamined, rediscovered, renewed, pp. 93-103, Routledge, New York.

Clark, A. \& Moss, P., 2011, Listening to young children: The Mosaic approach, 2nd edn., National Children's Bureau, London.

Cox, S., Drew, S., Guillemin, M., Howell, C., Warr, D. \& Waycott, J., 2014, 'Guidelines for ethical visual research methods', The University of Melbourne, Melbourne, viewed 01 May 2014, from http://vrc.org.au/guidelines-for-ethical-visualresearch-methods

Davies, B., 2014, Listening to children: Being and becoming, Routledge, London.
Department of Basic Education, 2011, National curriculum statement. Curriculum and assessment policy, foundation phase grades R-3. English home language, Government Printing Works, South Africa.

Doonan, J., 1983, Looking at pictures in picture books, Thimble Press, Stroud.

Egan, K., 1993, 'The other half of child', in M. Lipman (ed.), Thinking, children and education, pp. 301-305, Kendall/Hunt, Montclair, NJ.

Fisher, R., 2001, 'Philosophy in primary schools: Fostering thinking skills and literacy, reading', viewed 27 December 2013, from http://teachertools.londongt.org/enGB/resources/Philosophy_in_primaries_fisher.pdf

Forman, G., 1994, 'Different media, different languages', in L.G. Katz \& B. Cesarone (eds.), Reflections on the Reggio Emilia approach; perspectives from ERIC/EECE: $A$ monograph series, no 6, pp. 37-46.

Haynes, J., 2008, Children as philosophers, Routledge, London.

Haynes, J. \& Murris, K., 2009, 'Opening up space for children's thinking and dialogue', Farhung Journal Special Issue on Philosophy for Children 22(69), 175-188.

Haynes, J. \& Murris, K., 2012, Picture books, pedagogy and philosophy, Routledge, New York.

Hopperstad, M.H., 2010, 'Studying meaning in children's drawings', Journal of Early Childhood Literacy 10(4), 430-452. http://dx.doi.org/10.1177/1468798410383251

Howie, S., Venter, E. \& Van Staden, S., 2006, 'The effect of Multilingual policies on performance and progression in reading literacy', South African Primary Schools, International Association for the Evaluation of Educational Achievement, (PIRLS Study), viewed 02 June 2012, from http://www.iea.nl/fileadmin/user_upload/ Study), viewed 02 June 2012, from http://www.iea.nl/fing
IRC2006/IEA_Program/PIRLS/Howie_et_al_2_final.pdf

Kendrick, M. \& McKay, R., 2009, 'Researching literacy with young children's drawings', in M. Narey (ed.), Making meaning, pp. 53-70, Springer, Canada.

Lewis, D., 2001, Reading contemporary picturebooks: Picturing text, Routledge, London. Lipman, M., 1991, Thinking in education, Cambridge University Press, Cambridge.

MacLure, M., 2013, 'Researching without representation? Language and materiality in post-qualitative methodology', Special Issue: Post-Qualitative Research International Journal of Qualitative Studies in Education $26(6), 658-667 . \mathrm{http}: / /$ dx.doi.org/10.1080/09518398.2013.788755

Malaguzzi, L., 1998, 'History, ideas, and basic philosophy: An interview with Lella Gandini', in C. Edwards, L. Gandini \& G. Forman (eds.), The hundred languages of children: The Reggio Emilia approach - advanced reflections, 2 edn., pp. 49-99, Ablex Publishing, Westport, CT.

Mavers, D., 2011, Children's drawing and writing. The remarkable in the unremarkable, Routledge, New York.

Murris, K., 2009, 'Philosophy with children: Part of the solution to the early literacy crisis in South Africa', European Early Education Research Journal, 22(1), n.p., http://dx.doi.org/10.1080/1350293X.2014.970856

Murris, K., 2014, 'Reading philosophically in a community of enquiry: Challenging developmentality with Oram and Kitamura's Angry Arthur', Children's Literature and Education 45(2), 145-165. http://dx.doi.org/10.1007/s10583-013-9205-8

Murris, K., 2016, The posthuman child: Educational transformation through philosophy with picturebooks, Routledge, London.

Mutonyi, H. \& Kendrick, M.E., 2011, 'Cartoon drawing as a means of accessing what students know about HIV/AIDS: An alternative method', Visual Communication 10(2), 231-249. http://dx.doi.org/10.1177/1470357211398447

Narey, M., 2009, Making meaning: Constructing multimodal perspectives of language, literacy and learning through arts-based early childhood education, Springer, Dordrecht.

National Education Evaluation \& Development Unit [NEEDU], 2013, 'The state of literacy teaching and learning in the foundation phase', viewed 03 May 2013, from http://www.politicsweb.co.za

Nikolajeva, M. \& Scott, C., 2000, 'The dynamics of picturebook communication' Children's Literature in Education (4), 225-239. http://dx.doi. org/10.1023/A:1026426902123

Rinaldi, C., 2006, In dialogue with Reggio Emilia: Listening, researching and learning Routledge Contesting Early Childhood Series, London.

Serafini, F., 2009, 'Understanding visual images in picturebooks', in J. Evans (ed.), Talking beyond the page: Reading and responding to picturebooks, pp. 10-25, Routledge, London.

Sipe, L., 2012, 'Revisiting the relationships between texts and pictures', Children's Literature in Education 43, 4-21. http://dx.doi.org/10.1007/s10583-011-9153-0

Soundy, C.S., 2012, 'Searching for deeper meaning in children's drawings', Childhood Education 88(1), 45-51. http://dx.doi.org/10.1080/00094056.2012.643718

Soundy, C.S. \& Drucker, M.F., 2010, 'Picture partners: A co-creative journey into visual literacy', Early Childhood Education Journal 37, 447-460. http://dx.doi. org/10.1007/s10643-010-0374-4

Thomson, P., 2008, 'Children and young people: Voices in visual research', in P. Thomson (ed.), Doing visual research with young children and young people, $\mathrm{pp}$. 1-21, Routledge, London.

Vecchi, V., 2010, Art and creativity in Reggio Emilia: Exploring the role and potential of ateliers in early childhood education, Routledge, London.

Whitfield, P., 2009, 'The heart of the arts: Fostering young children's ways of knowing', in M.J. Narey (ed.), Making meaning: Constructing multimodal perspectives of language, literacy, and learning through arts-based early childhood education, pp. 153-165, Springer, New York.

Wormell, C., 2004, The big, ugly monster and the little stone rabbit, Random House, London. 